\title{
ONLINE Computer Library Center
}

Murilo Bastos da Cunha

Universidade de Brasília, Departamento de

Ciência da Informação e Documentação.

The 2003 OCLC environmental scan: pattern recognition: a report to the OCLC membership. Dublin, Ohio: OCLC, 2004. 150 p. ISBN: $1-55653-351-9$

Como parte de seu planejamento estratégico anual, o Online Computer Library Center (OCLC) preparou um relatório em que examinou os fatores externos que influenciam o ambiente bibliotecário. Esse documento foi distribuído aos membros do OCLC no início de 2004.

"No verão de 2003 [julho a setembro], a equipe do OCLC entrevistou 100 bibliotecários, fornecedores, arquivistas e outras pessoas que atuam no mundo da informação e identificou 300 artigos técnicos relevantes. A equipe do OCLC também organizou grupos de estudos com pessoas idosas, professores e alunos do ensino fundamental e do ensino médio. Ela coletou dados de gastos com educação, bibliotecas e tecnologia em 29 países. Esses países representam cerca de $60 \%$ da população mundial e $85 \%$ do PIB mundial. (...) A finalidade do relatório é identificar e descrever questões e tendências que têm ou terão impacto na OCLC, nas bibliotecas, nos museus, nos arquivos e em outras organizações associadas, seja positivo ou negativo" (p. ix).

O relatório é dividido em cinco cenários: social, econômico, tecnológico, pesquisa e ensino. No cenário social, são abordados os aspectos relacionados com o auto-atendimento, tendendo para a auto-suficiência aqui se insere o uso crescente dos mecanismos de busca na recuperação da informação necessária no dia-a-dia do usuário. É sintomática a afirmativa de Craig Silverstein, diretor de tecnologia do Google, em artigo na Newsweek, de 29 de março de 2004, de que o "o objetivo fundamental é ter um computador dotado do tipo de conhecimento semântico que um bibliotecário possui". Ressalta-se que essa foi a única menção a bibliotecas no artigo sobre o Google ou em toda essa edição do periódico! Nesse mesmo cenário é comentado o perfil padrão do novo usuário, geralmente um jovem que possui experiência no uso dos produtos e serviços da Internet.

Em relação ao cenário econômico, são discutidos, em nível mundial, os aspectos ligados aos gastos com educação e bibliotecas. Esses gastos, de uma maneira geral, mostram uma tendência de estabilização ou mesmo redução. Parece que o setor público, responsável por cerca de $87 \%$ dos investimentos totais, continuará a ser um dos maiores fornecedores dos recursos financeiros alocados nessas áreas. Aqui vale a pena apontar que, em 2000, 75\% dos gastos mundiais com bibliotecas foram realizados em somente cinco países (Estados Unidos, Reino Unido, Itália e França). Tal fato demonstra, de forma cabal, a crescente diferença entre os contextos bibliotecários desses cinco países e os restantes das outras nações. Sem recursos suficientes, as bibliotecas dos demais países terão, cada vez mais, dificuldades para ampliar e modernizar os produtos e serviços providos a seus usuários.

No cenário tecnológico, são discutidos o enorme esforço para estruturação dos dados não-estruturados dos diferentes suportes informacionais e a conexão física, até 2010, visando à ampla interligação das várias redes com os dos grupos que produzem informação; em 2015, será a fase da conexão lógica, incluindo-se aí a maturidade das redes sem fio e a Web semântica. Também são mencionados a migração para o software livre, a importância crescente do gerenciamento da segurança, autenticação e direitos digitais (que tende a permanecer como uma questão aberta nos próximos anos) e os desafios técnicos e econômicos da preservação digital.

No último cenário, pesquisa e aprendizado, são comentadas a redução das verbas e a proliferação do aprendizado eletrônico, especialmente via ensino a distância, bem como a aprendizagem vitalícia na comunidade, isto é, as pessoas tenderiam a aprender coisas novas ao longo de toda a vida. Nesse cenário, também é abordado o crescimento dos novos papéis a serem desempenhados pelos repositórios institucionais que provêem acesso livre à informação. $\mathrm{O}$ documento causou tanto sucesso e interesse, que o Conselho Diretor do OCLC decidiu dar-lhe ampla divulgação. Ele está disponível em texto integral, para acesso gratuito, no sítio do OCLC no URL: www.oclc.org/ membership/escan/default.htm. Um resumo em português, com 17 páginas, também está disponível na página principal do OCLC. O documento impresso, na versão em inglês ou em espanhol (Análisis del entorno de 2003 por OCLC: reconocimiento de patrones), é vendido por 15 dólares.

O relatório é de vital importância para aqueles que se preocupam com o futuro das bibliotecas, dos arquivos e de outros tipos de unidades informacionais. A sua leitura traz enorme quantidade de dados sobre as possíveis tendências que essas organizações enfrentarão nos anos vindouros, servindo, por conseguinte, de alerta e direcionamento para um planejamento estratégico dessas organizações. 
